\title{
GAMBARAN PENGETAHUAN IBU TENTANG KEJADIAN IKUTAN PASCA IMUNISASI (KIPI) DASAR LENGKAP DI KLINIK SEHAT KECAMATAN TAMBUSAI UTARA KABUPATEN ROKAN HULU TAHUN 2015
}

\author{
Hanna Sriyanti Saragih, Tety Refika \\ Jurusan Kebidanan Medan Poltekkes Kemenkes Medan
}

\begin{abstract}
Abstrak
Salah satu indikator penting dari setiap makhluk hidup dengan mempertahankan diri terhadap penyakit mikroba seperti, virus, bakteri parasit dan jamur, tubuh mempunyai cara mengatasi penyakit sampai batas tertentu. Dan defenisi KIPI merupakan sebagai reaksi simpang yang dikenal sebagai kejadian ikutan pasca imunisasi (KIPI) atau advers events following immunization (AEFI) adalah kejadian medik yang berhubungan dengan imunisasi baik berupa efek vaksin ataupun efek samping, toksisitas, reaksi sensivitas, efek farmakologis, atau kesalahan program, koinsidensi, reaksi suntikan atau hubungan kasual yang tidak dapat ditentukan. Penelitian ini bersifat deskriptif dengan jumlah soal 20 buah, responden dan sebagian sampel 30 orang. Penelitian ini menggunakan desain cross sectional yang artinya dependent yang mempengaruhi gambaran pengetahuan ibu tentang kejadian ikutan pasca imunisasi dasar lengkap (KIPI) antara lain umur, pendidikan, paritas, pekerjaan, dan sumber informasi. Pengumpulan data dilakukan dengan menggunakan kuesioner dalam bentuk presentase dalam bentuk kategori. Pengetahuan responden tentang KIPI dari 30 responden, mayoritas berpengetahuan kurang 21 orang (70\%), Cukup sebanyak 5 orang $(16,7 \%)$, dan minoritas baik sebanyak 4 orang $(13,33 \%)$. Berdasarkan penelitian ini dapat disimpulkan bahwa pengetahuan ibu tentang KIPI masih kurang. Diharapkan tenaga kesehatan di Klinik Sehat Kecamatan Tambusai Utara Kabupaten Rokan Hulu, agar lebih berperan aktif dalam meningkatkan pelayanan kesehatan dan diharapkan juga kepada ibu yang memiliki bayi 0-1 tahun agar rutin membawa anaknya ke Klinik dan selalu mengikuti pelayanan kesehatan.
\end{abstract}

Kata kunci: Pengetahuan Ibu, Kejadian Ikutan Pasca Imunisasi (KIPI) Dasar Lengkap

\section{LATAR BELAKANG}

Menurut Slamet tahun 2011 kegiatan imunisasi merupakan upaya yang paling cost effective dalam menurunkan angka kesakitan dan kematian akibat penyakit yang dapat dicegah dengan imunisasi (PD3I) yang diharapkan akan berdampak pada penurunan angka kematian bayi dan balita. Namun, data dari WHO (World healt organitation) Immunization Summary 2010 menunjukkan cakupan beberapa imunisasi dasar di Indonesia berkurang. Pada tahun 2008, cakupan DPT3 dan Polio3 adalah $77 \%$, cakupan Hepatitis B meningkat ke $78 \%$ namun masih belum mencapai target $80 \%$, cakupan BCG pula adalah $89 \%$. (Dahlia, 2013)

Menurut data Survei Demografi dan Kesehatan Indonesia tahun 2007, angka kematian neonatal di Indonesia sebesar 19 kematian/1000 kelahiran hidup, angka kematian bayi sebesar 34 kematian/1000 kelahiran hidup dan angka kematian balita sebesar 44 kematian/1000 kelahiran hidup. (Lestari \& Masruroh, 2012)

Menurut prince tahun 2011 Cakupan imunisasi dasar pada bayi di Indonesia pada tahun 2008 : BCG 93,2\%, DPT/HB(1) 95,7\%, DPT/HB(2) 93,1\%, DPT/HB(3) 91,4\%, Polio-1 97,9\%, Polio-2 94,5\%, Polio-3 92,2\%, Polio-4 89,9\% dan Campak 90,5\%.
Tingginya angka kematian bayi dan balita di indonesia menyebabkan turunnya derajat kesehatan. Kirakira 3 dari 100 kelahiran bayi akan meninggal karena penyakit campak. Sebanyak 2 dari 100 kelahiran bayi akan meninggal karena penyakit tetanus. Dari 200.000 bayi, 1 akan menderita penyakit polio. Imunisasi yang dilakukan dengan memberikan vaksin tertentu akan melindungi bayi terhadap penyakit-penyakit tertentu menurut proverawati.

Program imunisasi bertujuan untuk memberikan kekebalan terhadap penyakit yang dapat dicegah dengan imunisasi, proporsi kematian bayi saat disebabkan karena tetanus neonatrium (TN) di indonesia cukup tinggi $67 \%$ dalam upaya mencegah TN maka imunisasi diarahkan kepada pemberian perlindungan bayi baru lahir dalam minggu-minggu pertama melalui ibu, eliminasi tetanus neonatrium merupakan salah satu target yang harus dicapai sebagai tindak lanjut dari word summit for children yaitu insiden 1/10.000 kelahiran hidup pada tahun 2000 . (Marimbi, 2010)

Menurut (Sunarti \& Hanum, 2010) pertahanan tubuh bayi dan balita belum begitu sempurna, untuk itu perlunya pemberian imunisasi dasar lengkap. Namun terkadang imunisasi menimbulkan efek samping seperti, demam tinggi pasca imunisasi DPT dan campak, diare pasca imunisasi polio, dan bengkak pasca imunisasi hepatitis B, 
sehingga membuat orang tua was-was dan tidak mau membawa anaknya untuk imunisasi lanjutan, Sehingga banyak kanak-kanak yang tidak diberi imunisasi karena kurangnya pengetahuan ibu tentang vaksin serta jadwal imunisasi, salah satunya mengenai kontraindikasi, kerisauan tentang kesan sampling serta komplikasi vaksin. Padahal efek samping ini bertanda baik karena membuktikan vaksin yang dimasukkan kedalam tubuh bekerja, tetapi kita tidak boleh menutup mata begitu saja terhadap fakta tersebut ada kalanya efek imunisasi ini bisa sangat berat bahkan berujung kamatian, Menurut Departemen Kesehatn RI disebut ' kejadian ikutan pasca imunisasi (KIPI).

Berdasarkan survei awal yang dilakukan peneliti tahun 2015 dari 10 ibu yang membawa anaknya imunisasi, hanya 4 orang ibu yang membawa anaknya kembali lagi untuk diberikan imunisasi lanjutan.

Oleh karena itu peneliti tertarik meneliti “ Bagaimana Gambaran Pengetahuan ibu tentang ikutan pasca imunisasi (KIPI) imunisasi dasar lengkap di Klinik SEHAT Kecamatan Tambusai Utara Kabupaten Rokan Hulu Tahun 2015".

\section{Rumusan Masalah}

Berdasarkan uraian diatas maka yang terjadi rumusan masalah dalam penelitian ini adalah bagaimana gambaran pengetahuan ibu tentang kejadian ikutan pasca imunisasi (KIPI) dasar lengkap di Klinik SEHAT Kecamatan Tambusai Utara, Kabupaten Rokan Hulu.

\section{Tujuan Penelitian}

Untuk mengetahui Pengetahuan ibu tentang kejadian ikutan pasca imunisasi (KIPI) dasar lengkap di Klinik SEHAT Kecamatan Tambusai Utara, Kabupaten Rokan Hulu.

\section{Manfaat Penelitian}

Hasil penelitian ini bermanfaat sebagai referensi bagi para peneliti selanjutnya mengenai kejadian ikutan pasca imunisasi (KIPI) dasar lengkap, memotivasi para ibu untuk memahami kejadian ikutan pasca imunisasi (KIPI) dasar lengkap dan menambah pengetahuan tentang kejadian ikutan pasca imunisasi (KIPI) dasar lengkap.

\section{METODE PENELITIAN}

\section{Jenis Penelitian Dan Desain Penelitian}

Jenis penelitian ini adalah penelitian deskriptif yaitu untuk mengetahui Gambaran Pengetahuan Ibu Tentang Kejadian ikutan Pasca Imunisasi (KIPI) Dasar Lengkap Di Klinik Sehat Kecamatan Tambusai Utara, Kabupaten Rokan Hulu tahun 2015. Desain penelitian yang digunakan bersifat deskriptif cross sectional.

\section{Lokasi dan waktu penelitian}

Lokasi yang dipilih untuk penelitian ini adalah di Klinik SEHAT Kecamatan Tambusai Utara Kabupaten Rokan Hulu tahun 2015. Waktu penelitian ini dilakukan pada bulan Januari sampai dengan April 2015.

\section{Populasi dan Sampel}

Populasi adalah seluruh ibu-ibu PUS yang berada di Klinik SEHAT Kecamatan Tambusai Utara Kabupaten Rokan Hulu yang berjumlah 30 orang. Total sampling design dengan jumlah sampel 30 orang

\section{Jenis Data dan Instrumen Penelitian}

Jenis data yang digunakan dalam penelitian ini adalah data primer dan sekunder.

Data primer dikumpulkan sendiri oleh peneliti dengan pemberian kuesioner dengan pertanyaan yang tertutup kepada kuesioner dengan pertanyaan yang tertutup kepada responden.

Pertanyaan ini tertutup dengan jumlah pertanyaan 20 soal dengan bentuk checklist dengan menggunakan skala guttman dengan interpretasi penilaian :

a. Skor untuk yang benar diberi nilai 1

b. Skor untuk yang salah diberi nilai 0

\section{Pengolahan dan Analisa Data}

Setelah data dikumpulkan maka dilakukan pengelolahan data dengan proses memeriksa (Editing), Memberi Kode (Coding), Penyusunan Data (Tabulating)

Analisa data yang dilakukan secara deskriptif dengan melihat presentase data yang terkumpul dan disajikan dalam bentuk tabel distribusi frekuensi dan analisa data dilanjutkan dengan membahas penelitian teori dan keputusan yang ada (Hidayat, 2011)

Presentase tersebut dengan membagi frekuensi setiap alternatife jawaban dengan jumlah responden kemudian dikalikan $100 \%$ atau dengan rumus :

Rumus : $\mathrm{P}=\mathrm{F} / \mathrm{N} \times 100 \%$

$\mathrm{P}=\mathrm{N} \times 100 \%$

$\mathrm{P}=$ presentase

$\mathrm{F}=$ jumlah jawaban yang benar

$\mathrm{N}=$ jumlah soal

Kemudian data penelitian tersebut di interprestasikan dengan menggunakan kriteria tingkat pengetahuan responden sebagai berikut:

Nilai 76 - 100\% benar 16 - 20 dengan keterangan baik Nilai $56-75 \%$ benar $12-15$ dengan keterangan cukup Nilai < 56\% benar <11 dengan keterangan kurang. (Ariani, 2014)

\section{HASIL DAN PEMBAHASAN}

\section{Hasil Penelitian}

\section{Distribusi frekuensi responden berdasarkan pengetahuan}

Distribusi pengetahuan responden tentang Kejadian Ikutan Pasca Imunisasi (KIPI) dasar lengkap dapat dilihat pada tabel 1 . 
Tabel 1. Distribusi Frekuensi Responden Berdasarkan Pengetahuan Ibu Tentang Kejadian Ikutan Pasca Imunisasi (KIPI) Dasar Lengkap Di Klinik SEHAT Kecamatan Tambusai Utara, Kabupaten Rokan Hulu Tahun 2015

\begin{tabular}{|c|c|c|c|c|c|c|c|c|c|}
\hline \multirow[t]{3}{*}{ No } & \multirow[t]{3}{*}{ Umur } & \multicolumn{6}{|c|}{ Pengetahuan } & \multicolumn{2}{|c|}{ Jumlah } \\
\hline & & \multicolumn{2}{|c|}{ Baik } & \multicolumn{2}{|c|}{ Cukup } & \multicolumn{2}{|c|}{ Kurang } & \multirow[b]{2}{*}{$\mathbf{F}$} & \multirow[b]{2}{*}{$\%$} \\
\hline & & $\mathbf{F}$ & $\%$ & $\mathbf{F}$ & $\%$ & $\mathbf{F}$ & $\%$ & & \\
\hline 1 & $<20$ Tahun & - & - & - & - & - & - & - & - \\
\hline 2 & $\begin{array}{l}20-29 \\
\text { Tahun }\end{array}$ & 3 & 10 & 3 & 10 & 8 & 26,7 & 14 & 46,7 \\
\hline 3 & $\begin{array}{l}30-39 \\
\text { Tahun }\end{array}$ & 1 & 3,33 & 2 & 6,7 & 12 & 40 & 15 & 50 \\
\hline 4 & $>40$ Tahun & - & - & - & - & 1 & 3,33 & 1 & 3,33 \\
\hline & Total & 4 & 13,33 & 5 & 16,7 & 21 & 70 & 30 & 100 \\
\hline
\end{tabular}

Berdasarkan penelitian tabel 1 dapat dilihat bahwa pengetahuan ibu tentang kejadian ikutan pasca imunisasi (KIPI) dasar lengkap, mayoritas memiliki pengetahuan kurang sebanyak 21 orang $(70 \%)$, dan minoritas baik sebanyak 4 orang $(13,33 \%)$.

\section{Distribusi frekuensi responden berdasarkan umur}

Distribusi pengetahuan ibu yang didapatkan berdasarkan umur dapat dilihat dari Tabel 2.

Tabel 2. Distribusi Frekuensi Tingkat Pengetahuan Ibu Tentang Kejadian Ikutan Pasca Imunisasi (KIPI) Dasar Lengkap Berdasarkan Umur di Klinik SEHAT Kecamatan Tambusai Utara, Kabupaten Rokan Hulu Tahun 2015

\begin{tabular}{rccc}
\hline No & Pengetahuan & Frekuensi & \% \\
\hline $\mathbf{1}$ & Baik & 4 & $\mathbf{1 3 , 3 3}$ \\
$\mathbf{2}$ & Cukup & 5 & $\mathbf{1 6 , 7}$ \\
$\mathbf{3}$ & Kurang & 21 & $\mathbf{7 0}$ \\
\hline & Total & $\mathbf{3 0}$ & $\mathbf{1 0 0}$ \\
\hline
\end{tabular}

Berdasarkan tabel 2 diatas dapat dilihat bahwa pengetahuan ibu tentang kejadian ikutan pasca imunisasi (KIPI) dasar lengkap berdasarkan umur dari 30 respponden adalah dari umur 20-29 tahun sebanyak 14 orang $(46,7 \%)$ dengan mayoritas berpengetahuan kurang sebanyak 8 orang $(46,7 \%)$, berpengetahuan cukup sebanyak 3 orang $(10 \%)$, dan berpengetahuan baik sebanyak 3 orang $(10 \%)$. Dari umur 30-39 tahun sebanyak 15 orang (50\%), dengan mayoritas berpengetahuan kurang sebanyak 12 orang (40\%), berpengetahuan cukup sebanyak 2 orang $(6,7 \%)$, dan kategori pengetahuan baik sebanyak 1 orang $(3,33 \%)$. Dari umur $>40$ tahun sebanyak 1 orang $(3,33 \%)$. Dengan mayoritas berpengetahuan kurang sebanyak 1 orang $(3,33 \%)$, berpengetahuan cukup dan baik tidak ada
3. Distribusi Frekuensi Tingkat Pengetahuan Ibu Tentang Kejadian Ikutan Pasca Imunisasi (KIPI) Dasar Lengkap Berdasarkan Pendidikan Di Klinik SEHAT Kecamatan Tambusai Utara, Kabupaten Rokan Hulu Tahun 2015

Tabel 3. Distribusi Frekuensi Tingkat Pengetahuan Ibu Tentang Kejadian Ikutan Pasca Imunisasi (KIPI) Dasar Lengkap Berdasarkan Pendidikan Di Klinik SEHAT Kecamatan Tambusai Utara, Kabupaten Rokan Hulu Tahun 2015

\begin{tabular}{|c|c|c|c|c|c|c|c|c|c|}
\hline \multirow[t]{3}{*}{ No } & \multirow[t]{3}{*}{ Pendidikan } & \multicolumn{6}{|c|}{ Pengetahuan } & \multicolumn{2}{|c|}{ Jumlah } \\
\hline & & \multicolumn{2}{|c|}{ Baik } & \multicolumn{2}{|c|}{ Cukup } & \multicolumn{2}{|c|}{ Kurang } & \multirow[b]{2}{*}{$\mathbf{F}$} & \multirow[b]{2}{*}{$\%$} \\
\hline & & $\mathbf{F}$ & $\%$ & $\mathbf{F}$ & $\%$ & $\mathbf{F}$ & $\%$ & & \\
\hline 1 & SD & 1 & 3,33 & 1 & 3,33 & 9 & 30 & 11 & 36,7 \\
\hline 2 & SMP & - & - & 2 & 6,7 & 9 & 30 & 11 & 36,7 \\
\hline 3 & SMA & - & - & 1 & 3,33 & 3 & 10 & 4 & 13,33 \\
\hline 4 & PT & 3 & 10 & 1 & 3,33 & - & - & 4 & 13,33 \\
\hline & Total & 4 & 13,33 & 4 & 13,33 & 21 & 70 & 30 & 100 \\
\hline
\end{tabular}

Berdasarkan tabel 3 di atas dapat dilihat bahwa tingkat pengetahuan ibu tentang kejadian ikutan pasca imunisasi (KIPI) dasar lengkap berdasarkan pendidikan dari 30 responden, pendidikan SD sebanyak, 11 orang dengan mayoritas berpengetahuan kurang sebanyak 9 orang $(30 \%)$, berpengetahuan cukup sebanyak 1 orang $(3,33 \%)$, dan minoritas berpengetahuan baik 1 orang sebanyak $(3,33 \%)$. Pendidikan SMP sebanyak 11 orang $(36,7 \%)$, dengan mayoritas berpengetahuan kurang sebanyak 9 orang (30\%), dengan minoritas berpengetahuan cukup sebanyak 2 orang $(6,7 \%)$, dan berpengetahuan baik tidak ada. Pendidikan SMA sebanyak 4 orang $(13,33 \%)$, dengan mayoritas berpengetahuan kurang sebanyak 3 orang $(10 \%)$, dengan minoritas berpengetahuan cukup 1 orang $(3,33 \%)$, dan berpengetahuan baik tidak ada. Pendidikan perguruan tinggi sebanyak 4 orang $(13,33 \%)$, dengan kategori berpengetahuan baik sebanyak 3 orang (10\%), berpengetahuan cukup sebanyak 1 orang $(3,33 \%)$, dan berpengetahuan kurang tidak ada.

4. Distribusi Frekuensi Tingkat Pengetahuan Ibu Tentang Kejadian Ikutan Pasca Imunisasi (KIPI) Dasar Lengkap Berdasarkan Paritas Di Klinik SEHAT Kecamatan Tambusai Utara, Kabupaten Rokan Hulu Tahun 2015

Tabel 4. Distribusi Frekuensi Tingkat Pengetahuan Ibu Tentang Kejadian Ikutan Pasca Imunisasi (KIPI) Dasar Lengkap Berdasarkan Paritas Di Klinik SEHAT Kecamatan Tambusai Utara, Kabupaten Rokan Hulu Tahun 2015

\begin{tabular}{llcccccccc}
\hline No & Paritas & \multicolumn{9}{c}{ Pengetahuan } & Jumlah \\
& & \multicolumn{3}{c}{ Baik } & \multicolumn{2}{c}{ Cukup } & \multicolumn{2}{c}{ Kurang } & \\
\cline { 3 - 10 } & & F & \% & F & \% & F & \% & F & \% \\
\hline $\mathbf{1}$ & Primipara & 1 & 3,33 & 1 & 3,33 & 3 & 10 & 5 & 16,7 \\
$\mathbf{2}$ & Skundipara & 1 & 3,33 & 2 & 6,7 & 5 & 16,7 & 8 & 26,7 \\
$\mathbf{3}$ & Multipara & 2 & 6,7 & 2 & 6,7 & 13 & 43 & 17 & 56,6 \\
\hline & Total & $\mathbf{4}$ & $\mathbf{1 3 , 3 3}$ & $\mathbf{5}$ & $\mathbf{1 6 , 7}$ & $\mathbf{2 1}$ & $\mathbf{7 0}$ & $\mathbf{3 0}$ & $\mathbf{1 0 0}$ \\
\hline
\end{tabular}

Berdasarkan tabel 4 diatas dapat dilihat bahwa berdasarkan paritas dari 30 responden, primipara sebanyak 5 orang $(16,7 \%)$, dengan mayoritas berpengetahuan kurang sebanyak 3 orang (10\%), berpengetahuan cukup sebanyak 1 orang $(3,33 \%)$, dan berpengetahuan baik 1 orang 
(3,33\%). Pada skundipara sebanyak 8 orang (26,7\%), dengan mayoritas bepengetahuan kurang sebanyak 5 orang $(16,7 \%)$, berpengetahuan cukup sebanyak 2 orang $(6,7 \%)$, dan berpengetahuan baik sebanyak 1 orang $(3,33 \%)$. Pada multipara sebanyak 17 orang $(56,6 \%)$, dengan mayoritas berpengetahuan kurang sebanyak 13 orang (43\%), berpengetahuan cukup sebanyak 2 orang $(6,7 \%)$, dan berpengetahuan baik sebanyak 2 orang $(6,7 \%)$.

5. Distribusi frekuensi tingkat pengetahuan ibu tentang kejadian ikutan pasca imunisasi (KIPI) dasar lengkap berdasarkan pekerjaan di Klinik SEHAT Kecamatan Tambusai Utara Kabupaten Rokan Hulu Tahun 2015

Tabel 5. Distribusi Frekuensi Tingkat Pengetahuan Ibu Tentang Kejadian Ikutan Pasca Imunisasi (KIPI) Dasar Lengkap Berdasarkan Pekerjaan Di Klinik SEHAT Kecamatan Tambusai Utara, Kabupaten Rokan Hulu Tahun 2015

\begin{tabular}{|c|c|c|c|c|c|c|c|c|c|}
\hline \multirow[t]{3}{*}{ No } & \multirow[t]{3}{*}{ Pekerjaan } & \multicolumn{6}{|c|}{ Pengetahuan } & \multicolumn{2}{|c|}{ Jumlah } \\
\hline & & \multicolumn{2}{|c|}{ Baik } & \multicolumn{2}{|c|}{ Cukup } & \multicolumn{2}{|c|}{ Kurang } & \multirow[b]{2}{*}{$\mathbf{F}$} & \multirow[b]{2}{*}{$\%$} \\
\hline & & $\mathbf{F}$ & $\%$ & $\mathbf{F}$ & $\%$ & $\mathbf{F}$ & $\%$ & & \\
\hline 1 & IRT & 1 & 3,33 & 2 & 6,7 & 17 & 56,6 & 20 & \\
\hline 2 & Wiraswasta & 1 & 3,33 & 3 & 10 & 14 & 13,33 & 8 & 26,7 \\
\hline 3 & PNS & 2 & 6,7 & - & - & - & - & 2 & 6,7 \\
\hline & Total & 4 & 13,33 & 5 & 16,7 & 21 & 70 & 30 & 100 \\
\hline
\end{tabular}

Berdasarkan tabel 5 di atas dapat dilihat bahwa tingkat pengetahuan ibu tentang kejadian ikutan pasca imunisasi (KIPI) dasar lengkap berdasarkan pekerjaan dari 30 responden, pekerjaan IRT sebanyak, 20 orang dengan mayoritas berpengetahuan kurang sebanyak 17 orang $(56,6 \%)$, berpengetahuan cukup sebanyak 2 orang $(6,7 \%)$, dan minoritas berpengetahuan baik 1 orang sebanyak $(3,33 \%)$. Pekerjaan wiraswasta sebanyak 8 orang $(26,7 \%)$, dengan mayoritas berpengetahuan kurang sebanyak 4 orang $(13,3 \%)$, dengan minoritas berpengetahuan cukup sebanyak 3 orang (10\%), dan berpengetahuan baik sebanyak 1 orang $(3,33 \%)$. Pekerjaan PNS sebanyak 2 orang $(6,7 \%)$, dengan mayoritas berpengetahuan baik sebanyak 2 orang $(6,7 \%)$, dengan minoritas berpengetahuan kurang dan cukup tidak ada.

6. Distribusi Frekuensi Tingkat Pengetahuan Ibu Tentang Kejadian Ikutan Pasca Imunisasi (KIPI) Dasar Lengkap Berdasarkan Sumber Informasi Di Klinik SEHAT Kecamatan Tambusai Utara, Kabupaten Rokan Hulu Tahun 2015

Tabel 6. Distribusi Frekuensi Tingkat Pengetahuan Ibu Tentang Kejadian Ikutan Pasca Imunisasi (KIPI) Dasar Lengkap Berdasarkan Sumber Informasi Di Klinik SEHAT Kecamatan Tambusai Utara, Kabupaten Rokan Hulu Tahun 2015

\begin{tabular}{cccccccccc}
\hline No & $\begin{array}{c}\text { Sumber } \\
\text { Informasi }\end{array}$ & \multicolumn{9}{c}{ Baik } & \multicolumn{3}{c}{ Cukup } & \multicolumn{2}{c}{ Kurang } & \multicolumn{1}{c}{ Jumlah } \\
\cline { 3 - 10 } & & F & \% & F & \% & F & \% & F & \% \\
\hline $\mathbf{1}$ & M. Cetak & - & - & 2 & 6,7 & 5 & 16,7 & 7 & 23,33 \\
$\mathbf{2}$ & $\begin{array}{c}\text { M. } \\
\text { Elektronik }\end{array}$ & - & - & - & - & 4 & 13,33 & 4 & 13,33 \\
& P. Kesehatan & 4 & 13,33 & 3 & 10 & 12 & 40 & 19 & 63,33 \\
\hline & Total & $\mathbf{4}$ & $\mathbf{1 3 , 3 3}$ & $\mathbf{5}$ & $\mathbf{1 6 , 7}$ & $\mathbf{2 1}$ & $\mathbf{7 0}$ & $\mathbf{3 0}$ & $\mathbf{1 0 0}$ \\
\hline
\end{tabular}

Berdasarkan tabel 6 di atas dapat dilihat bahwa tingkat pengetahuan ibu berdasarkan sumber informasi dari 30 responden adalah terdapat 7 orang yang mendapatkan sumber informasi tentang kejadian ikutan pasca imunisasi (KIPI) dasar lengkap dari media cetak dengan mayoritas berpengetahuan kurang sebanyak 5 orang $(16,7 \%)$, berpengetahuan cukup sebanyak 2 orang $(6,7 \%)$, dan berpegetahuan baik tidak ada. Terdapat 4 orang yang mendapatkan sumber informasi tentang kejadian ikutan pasca imunisasi (KIPI) dasar lengkap dari dari media elektronik yang berpengetahuan kurang sebanyak 4 orang (13,33\%), dan berpengetahuan cukup dan baik tidak ada. Sumber informasi dari Petugas kesehatan berpengetahuan mayoritas berpengetahuan kurang sebanyak 12 orang (40\%), berpengetahuan baik sebanyak 4 orang $(16,7 \%)$, dan minoritas berpengetahuan cukup sebanyak 3 orang $(10 \%)$.

\section{PEMBAHASAN}

Dari hasil penelitian mengenai gambaran pengetahuan ibu tentang kejadian ikutan pasca imunisasi (KIPI) dasar lengkap di Klinik Sehat Kecamatan Tambusai Utara, Kabupaten Rokan Hulu Tahun 2015 maka hasil pembahasannya adalah :

\section{Berdasarkan Pengetahuan}

Dari hasil penelitian dapat diketahui bahwa dari 30 responden mayoritas berpengetahuan kurang sebanyak 21 orang $(70 \%)$. Dan minoritas berpengetahuan baik sebanyak 4 orang $(13,33 \%)$.

Berdasarkan dari data diatas dapat dilihat data tersebut sesuai teori yaitu pengetahuan adalah kesan didalam pikiran manusia sebagai hasil penggunaan panca indranya. Pengetahuan sangat berbeda dengan kepercayaan (beliefs), takhayul (superstition), dan peneranganpenerangan yang keliru (misinformation). Pengetahuan adalah segala apa yang diketahui berdasarkan pengalaman yang didapatkan oleh setiap manusia. Pengetahuan merupakan hasil mengingat suatu hal, termasuk mengingat kembali kejadian yang pernah dialami baik secara sengaja maupun tidak disengaja dan ini terjadi setelah orang melakukan kontak atau pengamatan terhadap suatu objek tertentu. (Mubarak hal 81, 2011).

\section{Pengetahuan Berdasarkan Umur}

Pengetahuan responden tentang kejadian ikutan pasca imunisasi (KIPI) dasar lengkap berdasarkan umur mayoritas pada kategori umur 30-39 tahun sebanyak 21 orang $(70 \%)$ dan minoritas pada kategori umur $>40$ tahun sebanyak 1 orang $(3,33 \%)$. Dan berpengetahuan baik dari 4 orang $(13,33 \%)$, mayoritas berada pada kategori umur 3039 yaitu 3 orang (10\%), dan minoritas berada pada kategori 20-29 tahun sebanyak 1 orang (3,33\%). Berpengetahuan cukup dari 5 orang (16,7\%), mayoritas pada kategori 20-29 tahun sebanyak 3 orang (10\%) dan minoritas berada pada umur 30-39 tahun sebanyak 2 orang (6,7\%). Berpengetahuan kurang dari 21 orang $(70 \%)$, mayoritas berpengetahuan kurang dari umur 30-39 tahun yaitu 16 
orang $(53,3 \%)$ dan minoritas pada kategori umur $>40$ tahun sebanyak 1 orang $(3,33 \%)$.

Menurut mubarak (2012) yaitu semakin cukup umur maka tingkat kematamgan dan kekuatan seseorang akan lebih matang dalam berfikir dan bekerja, sehingga pengetahuan yang diperolehnya semakin membaik.

Menurut asumsi penulis dengan bertambahnya umur ibu tidak menjamin bertambahnya pengetahuan tentang kejadian ikutan pasca imunisasi (KIPI) dasar lengkap sebaliknya, yang berusia lebih muda bisa saja berpengetahuan lebih baik karena ibu yng berusia muda memperoleh informasi yang banyak, dan daya tangkapnya lebih cepat. Dan berusia tua kemungkinan sudah malas mencari informasi hal ini disebabkan karena kesibukan pekerjaan dan daya tangkap ibu lambat sehingga masih sulit untuk menyerap informasi dalam kesehatan serta kurangnya keinginan PUS membaca dalam mencari informasi.

\section{Pengetahuan Berdasarkan Pendidikan}

Pengetahuan ibu tentang kejadian ikutan pasca imunisasi (KIPI) dasar lengkap berdasarkan pendidikan mayoritas pada tingkat SD dan SMP yaitu 11 orang (36,7\%). Dan minoritas pada tingkat pendidikan SMA dan PT yaitu 4 orang (13,33\%). Dan berpengetahuan baik dari 4 orang mayoritas berada pada pendidikan PT yaitu 3 orang (10\%), minoritas pada pendidikan SD 1 orang $(3,33 \%)$. Berpengetahuan cukup 5 orang (16,7\%), mayoritas pada pendidikan SMP sebanyak 2 orang $(6,7 \%)$, minoritas pendidikan SD, SMA, PT sebanyak 1 orang $(3,33 \%)$. Berpengetahuan kurang dari 21 orang (70\%), mayoritas pada pendidikan SD dan SMP yaitu 9 orang (30\%), minoritas pendidikan SMA sebanyak 3 orang $(10 \%)$.

Menurut asumsi penulis, tingkat pendididkan juga salah satu faktor yang dapat mempengaruhi pengetahuan seseorang untuk dapat lebih mudah menerima informasi hal-hal yang baru, namun ada kalanya pengalaman yang diterima seseorang tidak sama, hal ini berkaitan dengan pengetahuan seseorang dalam hal tertentu. Dari data yang diperoleh setelah dilakukan penelitian.

\section{Pengetahuan Berdasarkan Paritas}

Pengetahuan responden tentang kejadian ikutan pasca imunisasi (KIPI) dasar lengkap berdasarkan paritas mayoritas pada kelompok paritas multipara sebanyak 17 orang $(56,6 \%)$, dan minoritas pada kelompok primipara 5 orang $(16,7 \%)$. Berpengetahuan baik 4 orang $(13,33 \%)$ mayoritas pada kelompok paritas multipara yaitu 2 orang $(6,7 \%)$ dan minoritas pada kelompok paritas primipara dan skundipara sebanyak 1 orang $(3,33 \%)$. Berpengetahuan cukup dari 5 orang $(16,7 \%)$, mayoritas pada kelompok paritas skundipara dan multipara sebanyak 2 orang $(6,7 \%)$ dan minoritas pada kelompok primipara yaitu 1 orang $(3,33 \%)$. Berpengetahuan kurang dari 21orang (70\%), mayoritas pada kelompok paritas multipara yaitu 13 orang (43\%), minoritas pada kelompok primipara sebanyak 3 orang $(10 \%)$.
Menurut asumsi penulis, bahwa paritas juga merupakan salah satu faktor yang dapat mempengaruhi responden untuk menambah pengalaman dan pengetahuan. Dari hasil penelitian bahwa pengetahuan responden berdasarkan paritas sesuai dengan teori semakin banyak pengalaman melahirkan maka pengetahuan juga semakin baik.

\section{Pengetahuan Berdasarkan Pekerjaan}

Pengetahuan ibu tentang kejadian ikutan pasca imunisasi (KIPI) dasar lengkap berdasarkan pekerjaan mayoritas pada tingkat IRT yaitu 20 orang $(66,7 \%)$. Dan minoritas pada tingkat PNS yaitu 2 orang $(6,7 \%)$. Dan berpengetahuan baik dari 2 orang mayoritas berada pada pekerjaan PNS yaitu 2 orang $(6,7 \%)$, minoritas pada pekerjaan IRT dan wiraswasta 1 orang (3,33\%). Berpengetahuan cukup 5 orang $(16,7 \%)$, mayoritas pada pekerjaan wiraswasta sebanyak 3 orang $(10 \%)$, minoritas pekerjaan IRT, sebanyak 2 orang $(6,7 \%)$. Berpengetahuan kurang dari 21 orang $(70 \%)$, mayoritas pada pekerjaan IRT yaitu 17 orang $(56,6 \%)$, minoritas pekerjaan wiraswasta sebanyak 4 orang $(13,33 \%)$.

Menurut asumsi penulis, tentang hasil penelitian bahwa pengetahuan yang dimiliki seorang ibu dalam menjalani profesinya sebagai pemberi pelayanan kesehatan kepada masyarakat tidak hanya dipengaruhi oleh faktorfaktor pendukung yang lainya yaitu kecerdasan, daya ingat, pendidikan, motivasi dan juga usia.

Pekerjaan merupakan kegiatan yang harus dilakukan terutama untuk menunjang kehidupan keluarga. Seseorang ibu yang bekerja akan mempunyai pengetahuan lebih yang didapat dari luar, alat elektronik sesuai perkembangan zaman, rekan kerja dll. Dengan melalui pekerjaan ibu juga dapat paham dan tahu tentang kejadian ikutan pasca imunisasi (KIPI) dasar lengkap.

\section{Pengetahuan Berdasarkan Sumber Informasi}

Pengetahuan responden tentang Kejadian Ikutan Pasca Imunisasi (KIPI) Dasar Lengkap berdasarkan sumber informasi mayoritas pada kelompok sumber informasi petugas kesehatan sebanyak 19 orang $(63,33 \%)$, dan minoritas pada kelompok media elektronik 4 orang $(13,33 \%)$. Berpengetahuan baik 4 orang (13,33\%) mayoritas pada kelompok petugas kesehatan yaitu 4 orang $(13,33 \%)$ dan minoritas pada kelompok M. Cetak dan M. Elektronik tidak ada. Berpengetahuan cukup dari 5 orang $(16,7 \%)$, mayoritas pada kelompok petugas kesehatan sebanyak 3 orang (10\%) dan minoritas pada kelompok M. Cetak yaitu 2 orang $(6,7 \%)$. Berpengetahuan kurang dari 21orang (70\%), mayoritas pada kelompok petugas kesehatan yaitu 12 orang (40\%), minoritas pada kelompok Media elektronik sebanyak 4 orang $(13,33 \%)$.

Menurut asumsi penulis, bahwa sumber informasi juga merupakan segala sesuatu yang menjadi perantaraan dalam menyambung informasi baik media maupun non media. Dengan informasi yang demikian ibu akan lebih paham dan tahu tentang kejadian ikutan pasca imunisasi (KIPI) dasar lengkap, sebaliknya ketidaktahuan akan membuat seseorang tidak peduli dan tidak mau tahu. 


\section{KESIMPULAN}

1. Pengetahuan ibu tentang kejadian ikutan pasca imunisasi (KIPI) dasar lengkap, yang diambil dari 30 responden mayoritas kurang yaitu sebanyak 21 orang (70\%).

2. Pendidikan ibu mayoritas SD sebanyak 11 orang $(36,7 \%)$, SMP sebanyak 11 orang $(36,7 \%)$, berpendidikan SMA sebanyak 4 orang $(13,33 \%)$, dan PT s

3. Mayoritas responden memiliki paritas multipara dan berpengetahuan kurang yaitu sebanyak 13 orang (43\%).

4. Mayoritas responden memiliki pekerjaan sebagai IRT yaitu sebanyak 20 orang $(66,7 \%)$, wiraswasta sebanyak 8 orang $(26,7 \%)$, dan PNS sebanyak 2 orang $(6,7 \%)$.

5. Mayoritas responden yang berpengetahuan kurang mendapatkan informasi dari tenaga kesehatan yakni 12 orang (40\%).

\section{SARAN}

Dari hasil penelitian yang didapat, maka muncul beberapa saran dari peneliti, yaitu :

1. Diharapkan penelitian ini berguna untuk meningkatkan wawasan dan pengetahuan peneliti tentang kurangnya kejadian ikutan pasca imunisasi (KIPI) dasar lengkap.

2. Diharapkan kepada pihak Klinik SEHAT agar memberikan penyuluhan dan informasi langsung kepada ibu tentang kejadian ikutan pasca imunisasi (KIPI) dasar lengkap.

3. Diharapkan kepada responden dapat meningkatkan pengetahuan dan sikap tentang kejadian ikutan pasca imunisasi (KIPI) dasar lengkap.

\section{DAFTAR PUSTAKA}

Ariani, P. A. (2014). Aplikasi Metodologi Penelitian Kebidanan Kesehatan Reproduksi. Yogyakarta: Nuha Medika.

Dahlia, d. (2013). Gambaran Pengetahuan dan Sikap Ibu Tentang Imunisasi Dasr Lengkap Pada Bayi. Ilmiah Perguruan Tinggi , 1-2.
Dewi, V. N. (2011). Asuhan Neonatus Bayi Dan Balita. Jakarta: Salemba Medika.

Hidayat, A. a. (2011). Metode Penelitian Kebidanan Dan Tehnik Analisis Data. Jakarta: Salemba Medika.

Lestari, R. I., \& Masruroh. (2012). Pengetahuan Ibu Tentang Imunisasi Dasar Lengkap Dengan Praktek Imunisasi Dasar Lengkap. Ilmiah Kesehatan Akbid Uniska Kendal (p. 2). Jawa Tengah: Media Sosial.

Lisnawati, L. (2011). Generasi Sehat Melalui Imunisasi. Jakarta: CV. Trans Info Media.

Marimbi, H. (2010). Tumbuh Kembang Status Gizi dan Imunisasi Dasar Pada Balita. Yogyakarta: Nuha Medika.

Maryanti, D. (2011). Buku Ajar Neonatus, Bayi Dan Balita. Jakarta: TIM.

Mubarak, W. I. (2012). Promosi Kesehatan Untuk Kebidanana. Jakarta: Salemba Medika.

Notoatmodjo, S. (2010). Metode Penelitian Kesehatan. Jakarta: Rineka Cipta.

Ranuh, G. I., \& Suyitno, h. (2011). Pedoman Imunisasi Di Indonesia. Jakarta: Badan Penerbit Ikatan Dokter Anak Indonesia.

Saepudin, M. (2011). Metedologi Penelitian Kesehatan Masyarakat. Jakarta: CV. Trans Info Media.

Sunarti, \& Hanum, M. (2010). Asuhan Kebidanan V (Kebidanan Komunitas). Jakarta: Trans Info Media. 